\title{
A lantern retort for small-scale gold extraction
}

\author{
Richard Kwasi Amankwah, Grace Ofori-Sarpong \\ Mineral Engineering Department, University of Mines and Technology, Tarkwa, P. O. Box 237, Ghana
}

Email address:

richard.amankwah@gmail.com (R. K. Amankwah), gofori-sarpong@umat.edu.gh (G. Ofori-Sarpong)

To cite this article:

Richard Kwasi Amankwah, Grace Ofori-Sarpong. A Lantern Retort for Small-Scale Gold Extraction. International Journal of Environmental Protection and Policy. Vol. 2, No. 5, 2014, pp. 161-167. doi: 10.11648/j.jepp.20140205.13

\begin{abstract}
Two major retorts used in small-scale gold mining operations to reduce mercury emissions, during amalgam distillation are the steel and thermex retorts. Steel retorts are not very popular due to the reported darkening of gold after retorting. In addition, its opaque nature prevents miners from observing the process directly. The Thermex glass retort introduced by the United Nations Industrial Development Organisation (UNIDO) is also not patronised due to the extended heating periods resulting from the low thermal conductivity of glass. This paper describes a new retort, the Lantern retort, a combination of highly conductive steel with transparent glass, and therefore, a potential solution to the above concerns. The Lantern retort has a shorter warm-up and amalgam distillation time, and the rate of heating is $1.81^{\circ} \mathrm{C} / \mathrm{s}$ while that of the Thermex is $1.49^{\circ} \mathrm{C} / \mathrm{s}$. For an amalgam of mass $20 \mathrm{~g}, 900 \mathrm{~s}$ was required to carry out complete distillation in the Lantern retort as against $2100 \mathrm{~s}$ in the Thermex. The height of the distillation column of the Lantern retort required to reduce mercury loss to below $1 \%$, as it is with the Thermex retort, is $2.5 \mathrm{~cm}$. Other advantages of the Lantern retort are that, it is less expensive and can withstand the harsh terrain of small-scale gold mining.
\end{abstract}

Keywords: Small-scale Mining, Gold, Mercury, Amalgamation, Retorting, Lantern Retort

\section{Introduction}

Small-scale gold mining is an important economic activity in developing countries where the geological environment is favourable. In this activity, mercury is widely used to amalgamate and separate gold from concentrates that are generally referred to as black sands. However, due to careless handling, mercury may be lost to the environment mainly through inefficient amalgam distillation techniques and spillage. The estimated amount of mercury released into the general environment per annum through small-scale activities is about 1000 tonnes. Veiga et al. (1) indicated that, about 200-250 tonnes of mercury are released in China, and 100-150 tonnes in Indonesia. Other countries, including Bolivia, Brazil, Colombia, Peru, Philippines, Venezuela, Ghana and Zimbabwe release up to 30 tonnes. In 2009, the United Nations Industrial Development Organisation (UNIDO) (2) estimated that there are about 30 million miners involved in this industry worldwide, and virtually all of them utilise mercury in gold recovery.

Mercury has severe health and environmental impacts on communities where small-scale gold mining takes place, and several interventions have been put in place to reduce or eliminate mercury use. These include reduction in mercury loss by the introduction of retorts and 'mercuryless' processes such as winnowing and direct smelting $(3,4,5,6)$.

Retorting improves on the efficiency of amalgam distillation and diminishes the escape of mercury fumes. Two major retorts available for use in small-scale operations around the world are the Thermex and steel retorts. Unfortunately, the miners do not patronize the Thermex glass retort due to long heating times, especially for large pieces of amalgam. Another major problem has to do with its fragile nature. The steel retort is also not accepted due to darkening of gold after retorting, and its opaque nature which prevents miners from observing the process directly. This paper outlines a new technology, known as the Lantern retort that has been developed for use by small-scale miners, and compares its performance with that of the well-known Thermex retort. The performance of the Lantern retort was not tested against that of the steel retort as the latter is less accepted by users due to darkening of gold after retorting. 


\section{Impact of Mercury on the Public Health of Small-Scale Mining Communities}

Small-scale gold mining has made significant socioeconomic impact on many individuals and communities. In the rural communities where mining takes place, the activity has provided jobs, reduced rural exodus, promoted local economic development and contributed towards poverty reduction $(7,8,9,10)$. Small-scale gold miners generally apply mercury to concentrates so as to form a physical alloy with the gold and effect separation from the heavy sands that are part of the concentrate. The amalgam is then heated to obtain sponge gold.

The negative impact of mercury on the public health of communities, where small-scale gold mining flourishes, has been documented by several researchers $(11,12)$. In addition, the policy challenges associated with mercury use and environmental stewardship of the miners have been researched extensively $(13,14,15,16,17,18)$.

Mercury is a toxic chemical and has attracted global concern due to its persistence in the atmosphere, and its ability to bio-transform into methyl-mercury in the aquatic environment $(19,20)$. Several studies $(6,20,21,22,23,24$, $25,26,27,28)$ have outlined some negative impacts of mercury pollution on human health. These negative effects include hand tremors, sleep disorders, headache, dizziness, fatigue and weakening of the immune system. In some of the studies, death as a result of mercury intoxication has been recorded $(5,23)$.

In Ghana, studies have been conducted in several small-scale mining communities to monitor the health effects of mercury on the inhabitants. In a study conducted in Dumasi, a small-scale gold mining village, on both miners and non-miners, $90 \%$ of the people affirmed a slight metallic taste and salivation problems. Twenty percent claimed to have tremors and $65 \%$ had sleep disorders. An examination of mercury levels in biological samples showed that about $86-91 \%$ of the population was exposed to mercury and about $50 \%$ of miners and $25 \%$ of non-miners were considered heavily intoxicated with mercury $(3,7)$. This indicates that there is an impact of mercury on the public health of this mining community and perhaps other villages where small-scale mining activities thrive. High mercury content of raw fish samples has also been documented $(5 ; 18)$.

\section{Interventions on Mercury Use}

Based on the levels of mercury intoxication recorded in studies in small-scale mining centres around the world, several interventions have been undertaken. These are aimed at either reducing mercury usage and loss into the environment or searching for alternatives so as to eliminate mercury usage. Some methods that have been suggested with the aim of eliminating mercury use include winnowing, coal gold agglomeration, direct smelting and leaching processes such as IGoli, Haber and cyanidation $(6,29)$. For small-scale mining centres where coarse gold particles are encountered, winnowing, direct smelting and amalgamation followed by retorting appear to be better processing methods.

The use of retorts is a major way of reducing mercury loss after amalgamation (19, 30, 31, 32, 33). Several types of retorts are available in small-scale mining centres around the world, with the major ones being the steel and Thermex glass retorts (Figs 1 and 2). Steel retorts are viewed with suspicion by small-scale miners largely because they are opaque and there are general concerns that gold infiltrates into the iron surfaces. In addition, the gold becomes darker or brownish due to its reaction with iron. The Thermex retort is thought to be the first commercially available glass retort ever produced (34). The recommended selling price is \$US520 and the manufacturers claim that warm-up time is shorter compared to metallic retorts. In addition, the transparent nature of the glass permits miners to watch the whole process of separation of mercury and gold.

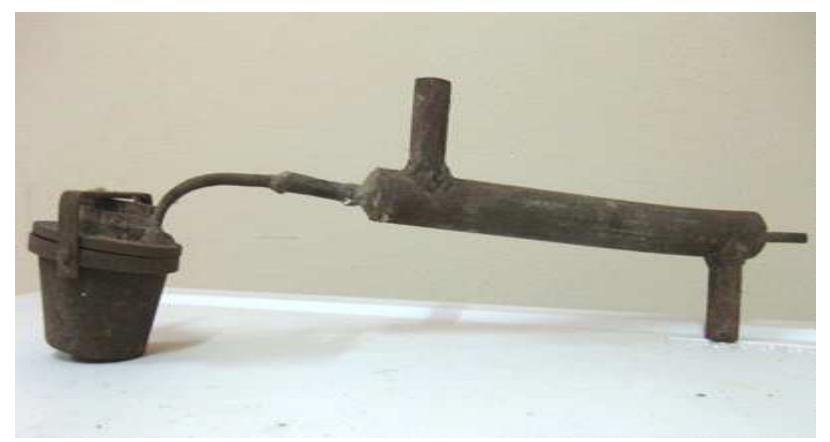

Fig 1. An example of the steel retort

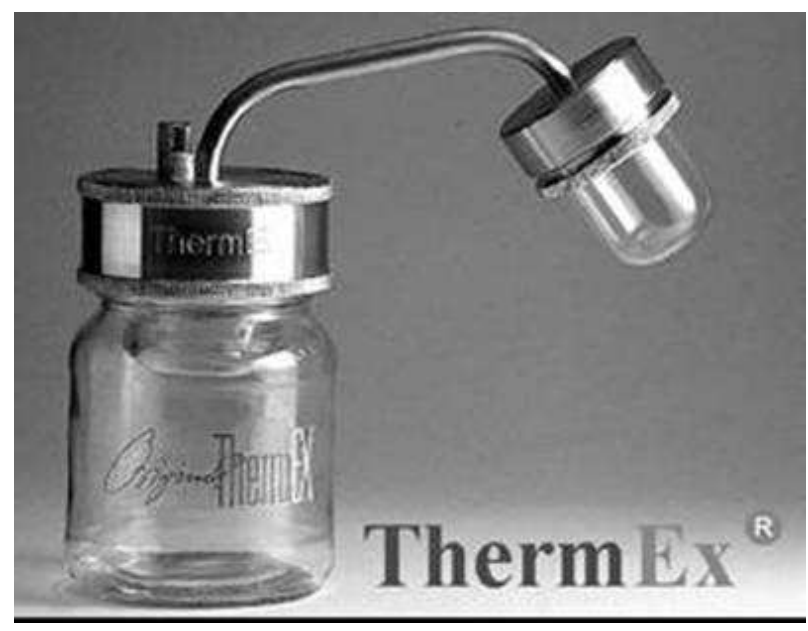

Fig 2. The Thermex glass retort (Babut et al, 2003)

Despite the claims by the manufacturers that Thermex heats faster and has better retorting kinetics, field investigations proved the contrary. As part of the European Union funded Ghana Mercury Abatement Project (35), extensive field investigations were conducted to ascertain why the miners do not patronize the Thermex glass retort. 
The study revealed that for relatively big amalgam balls, complete distillation of mercury may not be achieved within $60 \mathrm{~min}$ (Fig 3) due to the low heat conducting properties of glass. In addition, after heating for that long, a miner needs a similar period to wait for the glass to cool down before dismantling the instrument. Furthermore, the fragile nature of the glass used makes the unit not suitable for the rugged terrain which is characteristic of small-scale mining areas.

Due to these challenges, small-sale miners continue to burn their amalgam in the open hearth, with a blowtorch or other burners, allowing escape of mercury fumes. Thus mercury continues to impact on the public health of both the miners and others in the immediate vicinity of the site. A new retort that combines the fast heating kinetics and robustness of steel, with a window that allows the operation to be observed by the operator may thus be more acceptable.

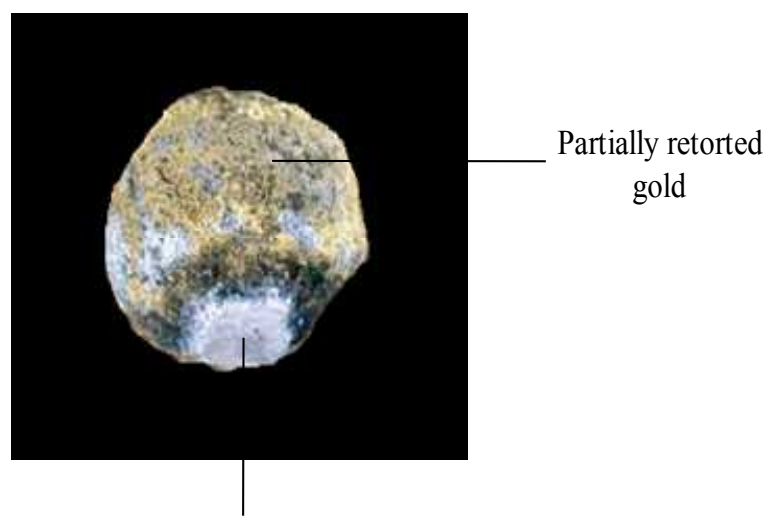

Un-touched section of amalgam after more than $60 \mathrm{~min}$ of heating

Fig 3. Incomplete amalgam distillation after over 60 minutes of distillation in the Thermex glass retort

\section{Experimental Investigations}

This study was conducted in Ghana where small-scale gold mining is a major activity in mineral-rich rural communities.

\subsection{Model Development and Operation}

Based on the limitations of the steel and glass retorts as reported by the miners, a new retort, the Lantern retort, was developed to combine the quick heating characteristics of steel with the see-through properties of glass so as to ensure transparency of the operation. The first model developed was built according to the conventional kerosene lantern lamp used in many communities in Ghana and the developing world as shown in Fig 4. The initial prototype stood at $20 \mathrm{~cm}$ on a circular platform of diameter $8 \mathrm{~cm}$. The metal platform which can be brought into direct contact with a heat source serves as a unit on which the amalgam can be placed. The transparent glass or quartz tubing has an average diameter of $5 \mathrm{~cm}$ and a height of $6 \mathrm{~cm}$. A pipe conducts mercury vapour into a receiver filled with water in which the mercury condenses.

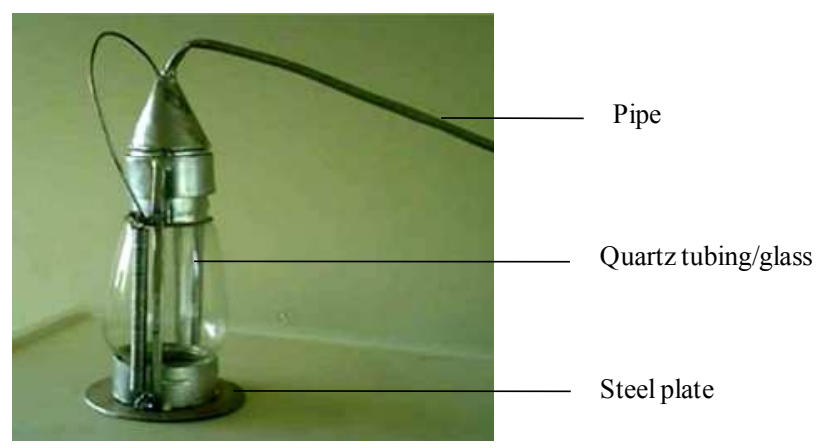

Fig 4. The Lantern Retort

A glass bulb or quartz tubing serves as a window through which an operator can observe the process. The bulb sits on an insulator which separates it from the metal base. The cone cap rests on the glass bulb and the contact is made air-tight through the use of retractable springs and a fibre coating which also serves as an insulator. The retractable springs allows the cone head to be moved upwards so the glass bulb can be removed or replaced in order to feed amalgam or remove the sponge gold after retorting.

During operation, the amalgam is wrapped in foil and placed on the platform in the unit. The use of the foil is necessary to prevent interaction between the steel platform and the amalgam during the heating process. The retort is brought into contact with the heat source which may be wood charcoal or a gas burner. The mercury distills off and the vapour passes through the inclined pipe which is inserted in cold water. The mercury collected under water can be reused for amalgamation.

\subsection{Comparative Tests between Thermex and Lantern Retorts}

Three tests were conducted in comparing the performance of the Thermex and Lantern retorts. These were the heating rate of the platform on which the amalgam will be placed, the amalgam distillation rate and the mercury loss during the distillation process. The heating rate of the platform was monitored by measuring the change in temperature with heating time using a K-type thermocouple. Weighed quantities of both mercury and amalgam were placed in the heating chamber of each retort, and the retorts were heated until the mercury was totally vapourised. Complete amalgam distillation was indicated by a constant mass of sponge gold. The time taken was recorded, and the liquid mercury recovered after the operation was also noted.

\subsection{Estimating an Appropriate Height for the Lantern Retort}

Based on initial test works, the mercury recovery efficiency of the lantern retort was found to be low and further tests were conducted to improve upon distillation and recovery efficiencies. Though there is little research on 
estimating the appropriate height of a retort, it is known that smaller diameters and shorter lengths are better (20). In these studies, retort units were made from $3.8 \mathrm{~cm}$ diameter galvanised iron pipe with varying distillation lengths of between $2.54 \mathrm{~cm}$ and $12 \mathrm{~cm}$ sealed at one end and threaded at the other end (Fig 5). A cone cap of length $2.54 \mathrm{~cm}$ was welded to an inclined discharge pipe of diameter $0.5 \mathrm{~cm}$ to conduct condensed mercury into a container. A cooling jacket made from plastic pipe fitted around the discharge pipe helps in the condensation of the mercury vapour. These components are shown in Fig 5. Once an appropriate height is established, a glass of that height would then be adopted. In these studies, $3 \mathrm{~g}$ of mercury was used in each case, and experiments were conducted in triplicate.

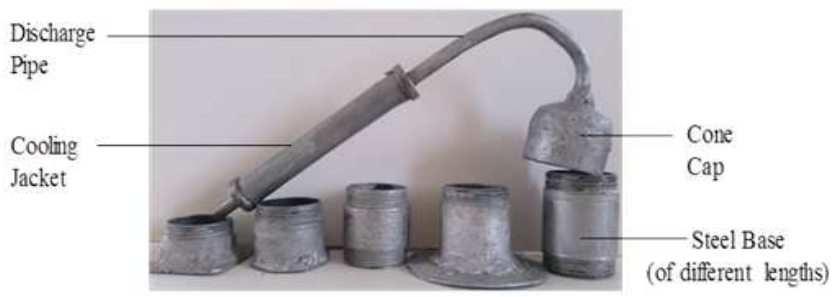

Fig 5. Components for the Retort Unit

\section{Results and Discussion}

The Lantern retort is an addition to the number of retorts available to small-scale gold miners. This new development combines the high heating kinetics of steel with the window that glass provides so that the miners can directly observe the gold amalgam while the process is going on; a requirement that miners are not willing to compromise on. Both laboratory and field investigations indicate that the Lantern retort is a viable alternative. The colour of gold obtained when amalgam is retorted is metallic yellow.

\subsection{Comparison of Heating Rate between Thermex and Lantern Retorts}

The Thermex and Lantern retorts were subjected to similar tests to determine the rise in temperature of the platform on which the amalgam is dropped, the rate at which mercury vaporises from the platform when heated and mercury loss during distillation. It was realised that the platform of the Lantern retort heated much more rapidly than that of the Thermex. For a period of $300 \mathrm{~s}$, the average temperature rise for the Lantern retort was $1.81^{\circ} \mathrm{C} / \mathrm{s}$ while that of the Thermex retort was $1.49^{\circ} \mathrm{C} / \mathrm{s}$. Fig 6 shows the vaporisation time as a function of mass of mercury placed in the two retorts.

It can be deduced that for the Thermex retort, $1 \mathrm{~g}$ of mercury required $250 \mathrm{~s}$ for complete vaporisation with the time increasing to $500 \mathrm{~s}$ at $5 \mathrm{~g}$ of mercury. With further increase in mass of mercury, the vaporisation time increased consistently reaching about $1150 \mathrm{~s}$ for $20 \mathrm{~g}$. For all masses of mercury used for the exercise, distillation rate of the Lantern was better than the Thermex retort. For example at $20 \mathrm{~g}$, the time for complete vaporisation in the Lantern retort was less than $800 \mathrm{~s}$, which is $30 \%$ lower than the time required in the Thermex.

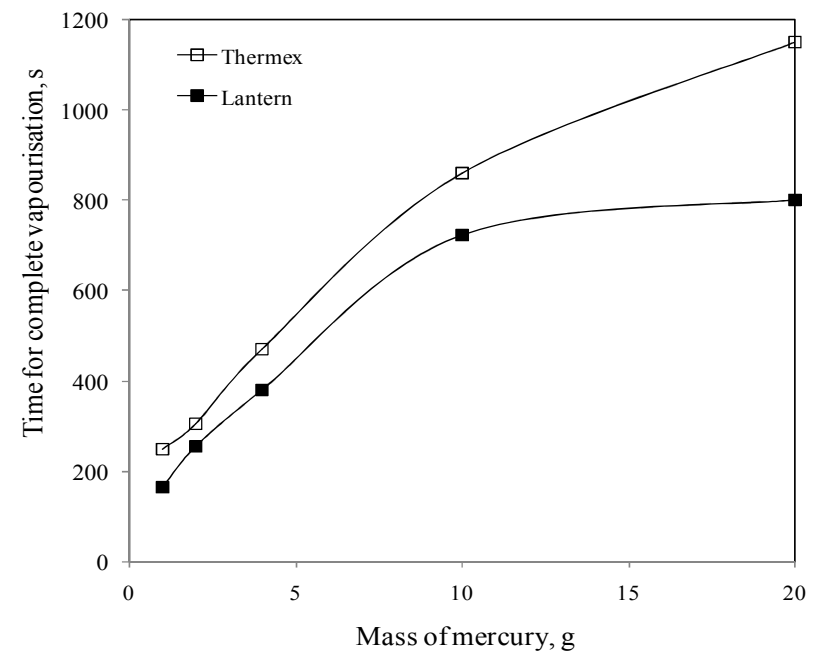

Fig 6. A comparison of mercury vapourisation using the Thermex and the Lantern retorts

\subsection{Amalgam Distillation Rate}

Fig 7 illustrates the mercury vapourisation rate when amalgam was used instead of clean mercury. For small masses of amalgam, the performance of both units were similar but as the masses increased beyond $5 \mathrm{~g}$, the Lantern retort performed better than the Thermex. For amalgam of masses, $10 \mathrm{~g}$ and $20 \mathrm{~g}$, it took $720 \mathrm{~s}$ and $900 \mathrm{~s}$ respectively to carry out complete distillation in the Lantern retort while the same masses of amalgam required $1500 \mathrm{~s}$ and $2100 \mathrm{~s}$ respectively in the Thermex. The faster amalgam distillation rate is due to the faster heating kinetics of the steel used in making the Lantern retort as opposed to the glass for the Thermex.

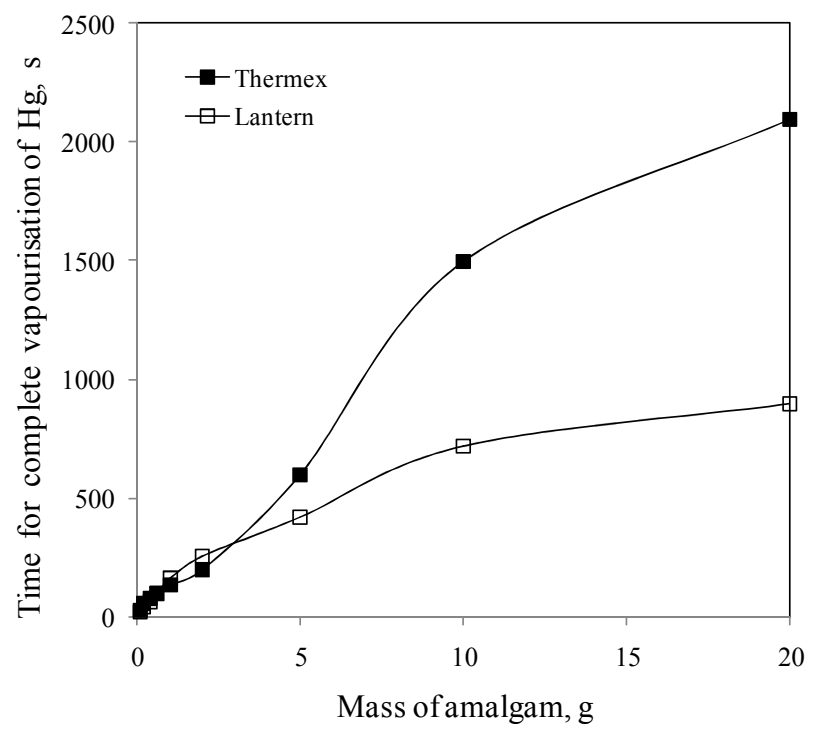

Fig 7. A comparison of amalgam distillation using the Thermex and the Lantern retorts 


\subsection{Effect of Distillation Height on Mercury Recovery}

In all the tests conducted, the mercury vapourised was collected and weighed to monitor the efficiency of mercury recovery. The mercury recovery efficiency for the Thermex was higher at above $99.5 \%$ while that of the Lantern was lower and variable. Further tests conducted on the effect of distillation height indicated that, of the units considered, 5.0 $\mathrm{cm}$ gave the maximum recovery of $99 \%$ (Fig 8 ). Heights up to $7.0 \mathrm{~cm}$ gave appreciable recoveries of $95 \%$.

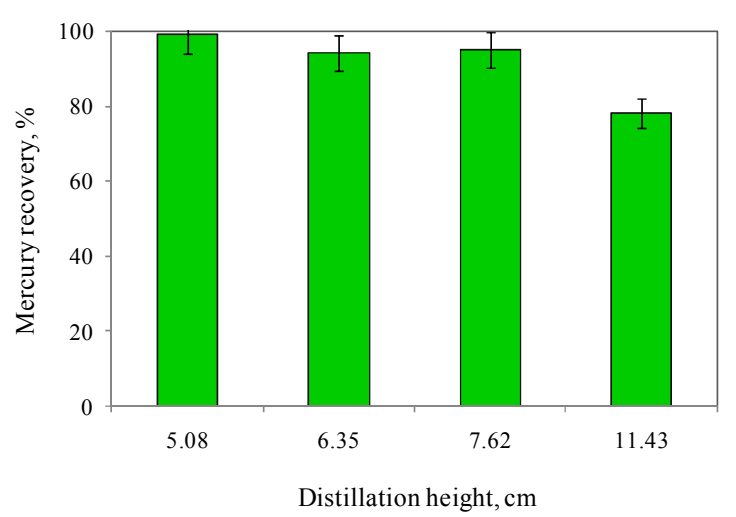

Fig 8. Effect of Retort Distillation height on Mercury Recovery

Based on the results from the experiments, another prototype was developed with the deduced height. The prototype as shown in Fig 9 has a distillation chamber of height, $5.0 \mathrm{~cm}$. The base is made up of a steel plate of height, $2.0 \mathrm{~cm}$ and diameter $5.0 \mathrm{~cm}$ which can be brought into contact with the heat source. An amalgam chamber of diameter, $3.5 \mathrm{~cm}$ and depth, $1.7 \mathrm{~cm}$ is created in the steel plate, and surrounded by a groove of depth, $0.5 \mathrm{~cm}$ in which the glass of diameter $3.7 \mathrm{~cm}$ sits. Both ends of the glass are coated with insulation to prevent direct contact with the metal units.

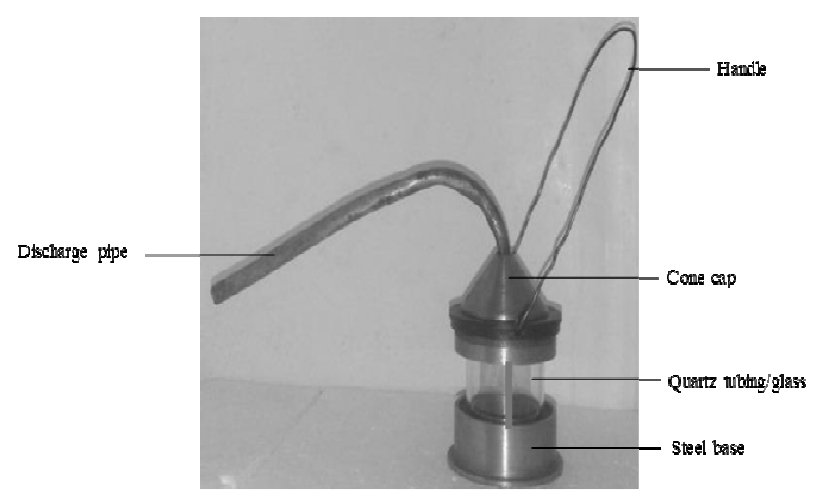

Fig 9. Improved Model of the Lantern Retort.

A galvanised iron cap with an inclined discharge pipe welded onto it, helps ensure an airtight contact and the discharge of condensed mercury into a receiver. The mercury collected can be reused. Metal rods connect the metal base to the cap on both sides, making it the set-up, air-tight. This arrangement also allows only the cone cap to be removed to receive the amalgam or for retorted gold to be taken out without necessarily removing the glass unit. The cost price of this promising retort is \$US 80 , about $15 \%$ the price of the Thermex.

\section{Conclusions}

A new retort, the Lantern retort, has been developed and tested for its ability in amalgam distillation and mercury recovery. The performance of the Lantern retort was compared with the Thermex glass retort, and it was realised that the Lantern heated at a rate of $1.81^{\circ} \mathrm{C} / \mathrm{s}$ while that of the Thermex was $1.49^{\circ} \mathrm{C} / \mathrm{s}$. Thus the Lantern retort had a shorter warm-up and amalgam distillation time. For amalgam of mass $20 \mathrm{~g}$, the period for complete distillation in the Lantern retort was $57 \%$ shorter than that in the Thermex.

Mercury loss from the Thermex retort was less than $1 \%$, and a similar value was attained for the Lantern at a distillation height of $5.0 \mathrm{~cm}$. Other advantages of the Lantern retort are that it costs less than $15 \%$ of the price of the Thermex, and it can withstand the harsh terrain of small-scale gold mining areas as it is more rugged.

\section{Acknowledgements}

The authors are grateful to Michael Tabbey-Appiah and Dickson Adjei for help with the experimental work, and Hayford of Shepekmog Engineers, Tarkwa, for assistance with the fabrication.

\section{References}

[1] M. M. Veiga, P. A. Maxson and L. D. Hylander, Origin and consumption of mercury in small-scale gold mining. Journal of Cleaner Production, 2006. Vol. 14 (3-4), pp. 436-447.

[2] Anon, United Nations Industrial Development Organization. Global Mercury Project Website. http://www.globalmercuryproject.org/.2009. Accessed on Aug/05/2009.

[3] M. Babut, R. Sekyi, A. Rambaud, M. Potin-Gautier, S. Tellier, W. Bannerman and C. Beinhoff, Improving the environmental management of small-scale gold mining in Ghana: a case study of Dumasi. Journal of Cleaner Production, 2003. Vol. 11 (2), pp. 215-221.

[4] L. D. Hylander and M.Meili, The Rise and fall of mercury: Converting a resource to refuse after 500 years of mining and pollution. Critical Reviews in Environmental Science and Technology, 2005. Vol. 35 (1), pp. 1-36.

[5] G. Hilson, C. J. Hilson S. and Pardie, Improving awareness of mercury pollution in small-scale gold mining communities: Challenges and ways forward in rural Ghana, Environmental Research, 2007. Vol. 103 (2), pp. 275-287.

[6] R. K. Amankwah, M. T. Styles, S. Al Hassan and R. S. Nartey, The application of direct smelting of gold concentrates as an alternative to mercury amalgamation in small-scale gold mining operations. International Journal of Environment and Pollution, 2010. Vol. 41 (3/4), pp. 304-315. 
[7] R. K. Amankwah and C. Anim-Sackey, Strategies for the sustainable development of the small-scale gold and diamond mining industry of Ghana. Resources Policy, 2003. Vol 29 (3-4): pp. 131-138

[8] N. Yakovleva, Perspectives on female participation in artisanal and small-scale mining: A case study of Birim North District of Ghana. Resources Policy, 2007. Vol. 32 (1-2), pp. 29-41.

[9] S. M. Banchirigah, Challenges with eradicating illegal mining in Ghana: A perspective from the grassroots. Resources Policy, 2008. Vol. 33 (1), pp. 29-38.

[10] G. Hilson, Child Labour in African Artisanal Mining Communities: Experiences from Northern Ghana. Development and Change, 2010. Vol. 41 (3), pp. 445-473.

[11] G. Drasch, S. Böse-O'Reilly, C. Beinhoff, G. Roider and S. Maydl, The Mt. Diwata study on the Philippines 1999 assessing mercury intoxication of the population by small-scale gold mining. The Science of the Total Environment, 2001. Vol. 267 (1-3), pp. 151-168.

[12] J. D. Appleton, T. M. Williams, N. Breward, A. Apostol, J. Miguel and C. Miranda, Mercury contamination associated with artisanal gold mining on the island of Mindanao, the Philippines. The Science of the Total Environment, 1999. Vol. 228 (2-3), pp. 95-109.

[13] W. Bannerman, M. Potin-Gautier and D. Amouroux, Mercury and arsenic in the gold mining regions of the Ankobra River basin in Ghana. Journal de Physique, 2003. Vol. 107, pp. 107-110.

[14] J. C. Bonzongo, A. K. Donkor and V. K. Nartey, Environmental impacts of mercury related to artisanal gold mining in Ghana. Journal de Physique IV, 2003. Vol. 107, pp. 217-220.

[15] P. Tschakert and K. Singha, Contaminated identities: Mercury and marginalization in Ghana's artisanal mining sector. Geoforum, 2007. Vol. 38 (6), pp. 1304-1321.

[16] G. Hilson and M. J. Clifford, Small-scale gold mining, the environment and human health: an introduction to the Ghana case. International Journal of Environment and Pollution, 2010. Vol. 41 (3-4), pp. 185-194.

[17] F. K. Nyame, Policy challenges on mercury use in Ghana's artisanal and small-scale mining sector. International Journal of Environment and Pollution, 2010. Vol. 41 (3-4), pp. 202-213.

[18] P. Tschakert, Mercury in fish: a critical examination of gold mining and human contamination in Ghana. International Journal of Environment and Pollution, 2010. Vol. 41 (3-4), pp 214-228.

[19] G. Hilson and R. Vieira, Challenges with minimising mercury pollution in the small-scale gold mining sector: Experiences from the Guianas. International Journal of Environmental Health Research, 2007. Vol. 17 (6), pp. 429-441.

[20] Anon. Reducing risks from mercury. OPPT Accomplishments Report, http://www.epa.gov/oppt/ar/2007-2009/reducing/mercury.ht m. 2014. Accessed: 09/ 02/ 2014

[21] A. A. Adimado and D. A. Baah, Mercury in Human blood, Urine, Hair, Nail, and Fish from the Ankobra and Tano river basins in Southwestern Ghana. Bull. Environ. Contam.Toxicol, 2002. Vol. 68, pp. 339-346.

[22] A. A. Golow and E. A. Adzei, Mercury in surface soil and cassava crop near an alluvial goldmine at Dunkwa-On-Offin, Ghana. Bull. Environ. Contam. Toxicol, 2002. Vol. 69, pp. 228-235.

[23] R. Eisler, Health risks of gold miners: A synoptic review. Environmental Geochemistry and Health, 2003. Vol. 25, pp. 325-345.

[24] J. J. Hinton, M. M. Veiga and C. Beinhoff, Women, Mercury, and Artisanal Gold Mining: Risk Communication and Mitigation. J. Phys. IV, 2003. Vol. 107, pp. 617-620.

[25] T. Iwata, M. Sakamoto, X. Feng, M. Yoshida, X. J. Liu, M. Dakeishi, P. Li, H. Jiang, M. Nakamura and K. Murata, Effects of mercury vapor exposure on neuromotor function in Chinese miners and smelters. Int. Arch Occup Environ Health, 2007. Vol. 80, pp. 381-387.

[26] R. B. Voegborlo, A. A. Adimado and J. H. Ephraim, Total mercury distribution in different tissues of Frigate Tuna (Auxisthazardthazard) from the Atlantic Coastal waters of Ghana, Gulf of Guinea. Environ. Monit. Assess., 2007. Vol. 132 , pp. 503-508

[27] R. K. Amankwah and G. Ofori-Sarpong, The lantern retort- A new retort for small-scale gold extraction, In: Proceedings of Precious Metals '10, June 15-16, Falmouth, UK, 2010. pp. $1-14$.

[28] M. T. Styles, R. K. Amankwah, S. Al-Hassan and R. Nartey, The identification and testing of a method for mercury-free gold processing for artisanal and small-scale gold miners in Ghana. Int. J. Environment and Pollution, 2010. Vol. 41 (3/4), pp. $289-303$.

[29] G. Hilson and A. J. Monhemius, Alternatives to Cyanide in the Gold Mining Industry: What Prospects for the Future? Journal of Cleaner Production, 2006. Vol. 14 (12-13): pp. $1158-1167$.

[30] G. Crispin, Environmental management in small-scale mining in PNG. Journal of Cleaner Production, 2003. Vol. 11 (2), pp. 175-183

[31] S. J. Spiegel, O. Savornin and D. Shoko, Mercury reduction in Munhena, Mozambique: Homemade solutions and the social context for change. International Journal of Occupational and Environmental Health, 2006. Vol. 12 (3), pp. 215-221.

[32] J. B. Jonsson, P. W. U. Appel and R. T. Chibunda, A matter of approach: the retort's potential to reduce mercury consumption within small-scale gold mining settlements in Tanzania. Journal of Cleaner Production, 2009. Vol. 17 (1), pp. 77-86.

[33] P. C. Velasquez-Lopez, M. M. Veiga and K. Hall, Mercury balance in amalgamation in artisanal and small-scale gold mining: identifying strategies for reducing environmental pollution in Portovelo-Zaruma, Ecuador. Journal of Cleaner Production, 2010. Vol. 18 (3), pp. 226-232.

[34] D. C. Israel and J. P. Asirot, Mercury Pollution Due to Small-Scale Gold Mining in the Philippines: An Economic Analysis, Philippine Institute for Development Studies, Paper Series No. 2000-06. Draft report, Economy and Environment Program for Southeast Asia. www.pids.gov.ph., 2000. 61 pp 
[35] M. T. Styles, K. P. C. DSouza, S. Al-Hassan, R. K. Amankwah, R. S. Nartey and W. Mutagwaba, Ghana Mining Sector Support Programme Project ACP GH 027, Mercury Abatement Phase 1 Report, 2006. 143 pp. 